\title{
Yersinia specific immune complexes in the synovial fluid of patients with yersinia triggered reactive arthritis
}

\author{
RIITTA LAHESMAA-RANTALA, ${ }^{1}$ KAISA GRANFORS , \\ HEIKKI ISOMÄKI, ${ }^{3}$ AND AULI TOIVANEN ${ }^{2}$
}

From the Departments of ${ }^{1}$ Medical Microbiology and ${ }^{2}$ Medicine, Turku University, Turku; and the ${ }^{3}$ Rheumatism Foundation Hospital, Heinola, Finland

SUMMARY Yersinia specific immune complexes were demonstrated in the synovial fluid of three $\dot{c}$ patients out of 12 with yersinia triggered reactive arthritis. They were not detectable in the $\vec{\circ}$

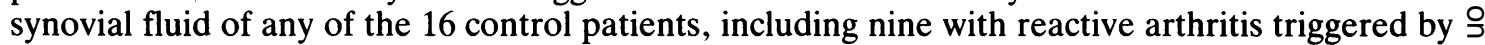
factors other than yersiniae. Platelet reactive IgG was detectable in the synovial fluid of eight out $\vec{c}$ of the 12 patients with yersinia triggered reactive arthritis and in three of the 16 control patients, all three having rheumatoid arthritis. An enzyme linked immunosorbent assay and a platelet ${ }^{125} \mathrm{I}$ labelled staphylococcal protein A test were used to measure yersinia specific immune complexes and platelet reactive IgG respectively. The results obtained show for the first time the occurrence of bacterial antigens, derived from the causative strain, in the synovial fluid in yersinia triggered reactive arthritis.

The pathogenesis of yersinia triggered reactive arthritis remains unknown. HLA-B27 is known to be associated with the development of this postinfectious complication, and certain interesting features characterise the immune response of the patients. ${ }^{12}$ For instance, circulating immune complexes (ICs) containing IgM and yersinia antigens occur more often in higher concentrations in patients with arthritis than in those without postinfectious complications. ${ }^{3}$ In some of the patients the ICs persist even up to one year after onset of the infection. The role of the ICs in the development of reactive arthritis remains unknown, however.

One of the main criteria for the pathogenetic significance of circulating ICs is their occurrence in the target organs. ${ }^{45}$ For yersinia triggered reactive arthritis an investigation has been reported in only two cases, ${ }^{6}$ in both of which synovial fluid ICs were detected by the platelet aggregation test; the nature of the antigen involved was not studied. In the present work we have studied the occurrence of yersinia specific and non-specific ICs in the synovial fluid of patients with yersinia arthritis.

Accepted for publication 13 March 1987.

Correspondence to Dr Riitta Lahesmaa-Rantala, Department of Medical Microbiology, Turku University, SF-20520 Turku, Finland.

\section{Patients and methods}

PATIENTS AND SAMPLES

Synovial fluid was obtained from 12 patients, 10 men and two women, with reactive arthritis triggered by Yersinia enterocolitica O:3 (Table 1). Yersiniosis was diagnosed on the basis of clinical symptoms, serology, and bacterial cultures. ${ }^{37}$ All patients developed typical reactive arthritis after the $\delta$ initial infection, with one or more joints involved. All the synovial fluid samples were taken from the o knee two to 11 weeks after onset of the initial infection. Synovial fluid cultures of blood ando chocolate agar were negative for micro-organisms from all samples. For controls, fluid was taken from $\mathcal{N}$ 16 patients with knee joints swollen for other N reasons; nine had reactive arthritis triggered by N factors other than yersiniae (Table 2). All synovial $\frac{\omega}{\sigma}$ fluids were centrifuged within one hour to remove cells and fibrous clots, and the supernatants were stored in small aliquots at $-40^{\circ} \mathrm{C}$ until used.

ENZYME LINKED IMMUNOSORBENT ASSAY (ELISA) FOR YERSINIA SPECIFIC ICS $A$ recently developed ELISA for the detection of $\frac{}{\mathbb{D}}$ yersinia specific ICs according to the immunoglobu- $\varrho$ lin class involved was applied. ${ }^{8}$ In the assay yersinia 
Table 1 Clinical features of the patients with yersinia triggered reactive arthritis

\begin{tabular}{|c|c|c|c|c|c|c|c|c|}
\hline \multirow{3}{*}{$\begin{array}{l}\text { Patient } \\
\text { No }\end{array}$} & \multirow{3}{*}{$\begin{array}{l}\text { Age } \\
\text { (years) }\end{array}$} & \multirow[t]{3}{*}{ Sex } & \multirow[t]{3}{*}{$H L A-B 27$} & \multirow{3}{*}{$\begin{array}{l}\text { Stool } \\
\text { culture }\end{array}$} & \multicolumn{3}{|c|}{ Clinical symptoms } & \multirow{3}{*}{$\begin{array}{l}E S R^{\dagger} \\
(\mathrm{mm} / \mathrm{h})\end{array}$} \\
\hline & & & & & \multirow[t]{2}{*}{ Diarrhoea } & \multicolumn{2}{|c|}{ Arthritis } & \\
\hline & & & & & & Acute & Chronic* & \\
\hline 1 & 46 & $\mathbf{M}$ & + & - & Yes & Yes & No & 77 \\
\hline 2 & 44 & M & + & - & Yes & Yes & No & 120 \\
\hline 3 & 30 & $\mathbf{M}$ & + & $\mathrm{O}: 3 \ddagger$ & Yes & Yes & No & 72 \\
\hline 4 & 41 & M & + & - & Yes & Yes & No & 85 \\
\hline 5 & 45 & M & + & - & Yes & Yes & No & 94 \\
\hline 6 & 17 & $\mathbf{M}$ & + & $0: 3$ & No & Yes & No & 55 \\
\hline 7 & 16 & $\mathrm{~F}$ & + & - & Yes & Yes & Yes & 37 \\
\hline 8 & 27 & M & + & - & Yes & Yes & No & 100 \\
\hline 9 & 31 & M & + & $\mathrm{O}: 3$ & Yes & Yes & No & 80 \\
\hline 10 & 27 & M & + & $0: 3$ & No§ & Yes & Yes & 75 \\
\hline 11 & 38 & $F$ & + & - & Yes & Yes & No & 97 \\
\hline 12 & 39 & M & + & $0: 3$ & Yes & Yes & Yes & 66 \\
\hline
\end{tabular}

All patients showed strong antibody response against Yersinia enterocolitica O:3 (IgM. IgG, and/or IgA as measured by enzyme immunoassay).

*Symptoms persisting for more than a year after the initial infection.

†The value observed at the time when synovial fluid was taken; ESR=erythrocyte sedimentation rate.

$\ddagger$ Yersinia enterocolitica O:3.

$\$$ Only abdominal pain.

Table 2 Clinical features of the control patients

\begin{tabular}{|c|c|c|c|c|c|c|}
\hline $\begin{array}{l}\text { Patient } \\
\text { No }\end{array}$ & $\begin{array}{l}\text { Age } \\
\text { (years) }\end{array}$ & Sex & $H L A-B 27$ & Diagnosis & Trigger of $\operatorname{Re} A^{*}$ & $\begin{array}{l}E S R \\
(\mathrm{~mm} / \mathrm{h})\end{array}$ \\
\hline 1 & 53 & $\mathrm{~F}$ & ND & $\operatorname{ReA}^{*}$ & Salmonella* & 33 \\
\hline 2 & 41 & $\mathbf{M}$ & ND & $\operatorname{Re} A$ & Salmonella & 36 \\
\hline 3 & 28 & M & + & $\operatorname{Re} A$ & Campylobacter* & 71 \\
\hline 4 & 34 & $\mathrm{~F}$ & + & $\operatorname{Re} A$ & Streptococcus* & 53 \\
\hline 5 & 41 & $\mathrm{~F}$ & - & $\operatorname{ReA}$ & Ulcerative colitis & 53 \\
\hline 6 & 46 & $\mathbf{M}$ & + & $\operatorname{Re} A$ & Unknown & 100 \\
\hline 7 & 21 & $\mathbf{M}$ & ND & $\operatorname{Re} A$ & Unknown & 71 \\
\hline 8 & 22 & $\mathrm{~F}$ & + & $\operatorname{Re} A$ & Unknown & 75 \\
\hline 9 & 21 & $\mathbf{M}$ & + & $\operatorname{Re} A$ & Unknown & 59 \\
\hline 10 & 27 & $\mathrm{~F}$ & ND & $\mathrm{RA}^{*}$ & & 48 \\
\hline 11 & 55 & $\mathbf{M}$ & ND & RA & & 31 \\
\hline 12 & 69 & $\mathbf{M}$ & ND & RA & & 26 \\
\hline 13 & 20 & $\mathbf{M}$ & ND & Juvenilc RA & & 19 \\
\hline 14 & 65 & $\mathrm{~F}$ & ND & Arthrosis of the knee & & 18 \\
\hline 15 & 35 & $\mathbf{M}$ & ND & Distension of the knee & & 24 \\
\hline 16 & 41 & $\mathbf{M}$ & - & Hyperuricaemia & & 36 \\
\hline
\end{tabular}

${ }^{*} \mathrm{ReA}=$ reactive arthritis; Salmonella $=$ Salmonella typhimurium $;$ Campylobacter $=$ Campylobacter jejuni: Streptococcus $=\beta$ haemolytic streptococcus, group $\mathrm{A} ; \mathrm{RA}=$ rheumatoid arthritis.

ICs are captured by the antibody to polystyrene microtitre plates by rabbit antihuman immunoglobulins, and the existence of $Y$ entercolitica $\mathrm{O}: 3$ antigens is demonstrated using Fab fragments of alkaline phosphatase conjugated antibody against the same serotype. Samples were diluted 1:20 in phosphate buffered saline $(0 \cdot 1 \mathrm{M}, \mathrm{pH} 7 \cdot 5)$ containing $5 \%$ normal rabbit serum. As control each plate included a positive serum with a high concentration of yersinia-immunoglobulin complexes of all three immunoglobulin classes, buffer, and a pool of sera from 50 healthy blood donors. Each sample from the healthy controls was also analysed separately to calculate a mean and standard deviation (SD). Optical density values at $405 \mathrm{nn}\left(\mathrm{OD}_{405}\right)$ exceeding by $2 \mathrm{SD}$ the values for the pooled normal controls present in each assay were taken as positive. All assays were performed in duplicate.

PLATELET ${ }^{125}$ I LA B E L LE D S T A P H Y L O C O C C A L
PROTEIN A TEST (PIPA)
Platelet reactive IgG, usually considered to repre- 
sent antigen non-specific ICs, was determined by a platelet ${ }^{125}$ I labelled staphylococcal protein A test (PIPA). The details of the test are described elsewhere. ${ }^{9}$ Human platelets were allowed to react with 1:10 diluted synovial fluids on microtitre plates. After washing, the binding of IgG through the Fc receptors to the test platelets was measured by radiolabelled protein $\mathrm{A}$. Results were expressed as SD units, calculated from a panel of normal sera included in each test. Values of more than 2SD above the mean for normal sera were considered positive.

DETERMINATION OF RHEUMATOID FACTOR Rheumatoid factor was determined in all samples from patients with yersinia triggered reactive arthritis by an ELISA for IgM rheumatoid factor. ${ }^{10}$

\section{Results}

In the patients with yersinia triggered reactive arthritis yersinia specific ICs were demonstrated in three out of 12 synovial fluids (Table 3 ). One patient (No 10) had a high level of yersinia IgM ICs $\left(\mathrm{OD}_{405}\right.$ $0 \cdot 778)$ and another patient (No 8) a low level $\left(\mathrm{OD}_{405}\right.$ $0.406)$. Yersinia IgA ICs were observed in one patient (No 7) at a low level $\left(\mathrm{OD}_{405} 0 \cdot 391\right)$. Assay for yersinia-IgG ICs was negative in all samples. All synovial fluid samples taken from the 16 control patients were negative for the yersinia specific ICs of all immunoglobulin classes.

Table 3 Occurrence of immune complexes (ICs) in the synovial fluid of patients with yersinia triggered reactive arthritis

\begin{tabular}{|c|c|c|c|c|}
\hline \multirow{2}{*}{$\begin{array}{l}\text { Patient } \\
\text { No }\end{array}$} & \multicolumn{3}{|c|}{ Yersinia specific $I C s^{*}$} & \multirow{2}{*}{$\begin{array}{l}\text { Platelet } \\
\text { reactive } \\
\mathrm{Ig}^{\dagger}\end{array}$} \\
\hline & $\lg M$ & $\lg G$ & $\operatorname{Ig} A$ & \\
\hline 1 & $0 \cdot 260$ & $0 \cdot 190$ & 0.226 & $<2 \cdot 0$ \\
\hline 2 & 0.288 & 0.278 & 0.252 & 3.0 \\
\hline 3 & 0.234 & 0.234 & 0.226 & $1 \overline{9 \cdot 4}$ \\
\hline 4 & $0 \cdot 296$ & $0 \cdot 274$ & $0 \cdot 250$ & $\overline{<2 \cdot 0}$ \\
\hline 5 & $0 \cdot 189$ & $0 \cdot 270$ & 0.212 & $21 \cdot 8$ \\
\hline 6 & 0.275 & $0 \cdot 289$ & 0.298 & $\overline{<2 \cdot 0}$ \\
\hline 7 & 0.295 & 0.262 & $0 \cdot 391$ & $6 \cdot 8$ \\
\hline 8 & 0.406 & 0.292 & 0.255 & $<2 \cdot 0$ \\
\hline 9 & $\overline{0 \cdot 277}$ & $0 \cdot 269$ & $0 \cdot 258$ & $\underline{4 \cdot 0}$ \\
\hline 10 & $\underline{0.778}$ & 0.268 & $0 \cdot 230$ & $1 \overline{6 \cdot 0}$ \\
\hline 11 & $\overline{0.234}$ & $0 \cdot 196$ & $0 \cdot 239$ & $\overline{9.4}$ \\
\hline 12 & 0.209 & $0 \cdot 258$ & 0.206 & $1 \overline{2 \cdot 4}$ \\
\hline
\end{tabular}

${ }^{*}$ Yersinia specific ICs of different immunoglobulin class were measured by an ELISA. The results are expressed as optical density values at $405 \mathrm{~nm}$. The limit for positivity (2SD over the mean of 50 normal controls) was 0.356 for yersinia-IgM ICs, 0.535 for yersinia-IgG ICs, and $\mathbf{0 . 3 8 5}$ for yersinia-IgA ICs. The values exceeding the limit are underlined.

†Platelet reactive IgG measured by PIPA is expressed as SD units. Values exceeding 2SD were considered positive (underlined).
A PIPA was positive in eight out of the $12 \frac{\mathrm{O}}{\mathrm{n}}$. synovial fluids taken from patients with yersinia? triggered reactive arthritis (Table 3 ). The synovial $\overrightarrow{\vec{m}}$ fluid of the three control patients with rheumatoidarthritis (Nos 10-12) had positive PIPA values of 7,등 16 , and $10 \mathrm{SD}$ units respectively. In all other controlo samples PIPA values remained negative.

Determinations of IgM rheumatoid factor in synovial fluids taken from patients with yersiniaes triggered reactive arthritis were negative.

\section{Discussion}

Our findings indicate the existence of yersinia? antigens in the form of ICs in the synovial fluid of patients with reactive arthritis after yersiniosis. We $v$ also believe that the occurrence of ICs containing $\rightarrow$ yersinia antigens in the synovial fluid in reactive arthritis is more common than shown by the present ${ }^{3}$ study (in three out of 12 patients) since different ${ }_{-}^{-}$ methods detect different ICs. ${ }^{11}$ This holds true for气 the ELISA of yersinia specific ICs and for the PIPA. PIPA detects platelet reactive IgG, which consists in $\bigodot_{\infty}$ the serum of antigen-IgG complexes, IgG aggre-.. gates, and sometimes also specific antibodies, e.g., antiplatelet and anti-HLA antibodies. ${ }^{12}$ For the ELISA of yersinia specific ICs that we used the antigen within the ICs must be exposed to be⿳亠丷 detected. ${ }^{8}$ Also, only one rabbit anti-yersinia serum $\mathbb{\complement}$ was applied; use of antisera detecting other epitopes $\overrightarrow{\vec{A}}$ might have increased the number of positive sam- $\frac{0}{3}$ ples. Therefore, synovial fluids positive only with as PIPA may contain yersinia antigens as well. A응 further possibility is that most of the yersinia specific ICs are phagocytosed by synovial fluid monocytes and granulocytes and are therefore not detectable in the supernatant.

The specificity of our findings is indicated by theô absence of yersinia specific ICs in the synovial fluid $₹$ of control patients. Nine of the controls were을 reactive arthritides triggered by factors other than $>$ yersiniae. Specificity of the assay has also been을. confirmed by inhibition experiments using $Y$ enterocolitica O:3 antigens ${ }^{3}$ and by dissociation of antigen $\sigma$ antibody complexes. ${ }^{13}$ Analysis by high pressure $\tilde{O}$ liquid chromatography of yersinia specific ICs in the sera of patients with yersiniosis has shown that theyg are relatively small in size. ${ }^{13}$

Interestingly, two of the three patients with detectable yersinia specific ICs in the synovial fluid? during the early stage of the disease continued to 7 have joint symptoms for at least a year after the

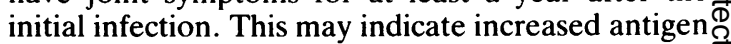
load in these patients, leading to formation of $\mathbb{Q}$ yersinia specific ICs in such amounts that theyo become detectable by the present method. Also, in 
our earlier study prolonged joint symptoms were observed in five out of the six patients with yersinia triggered reactive arthritis, who still had circulating yersinia specific ICs over eight months after the onset of infection. ${ }^{3}$ These findings speak for the role of persisting microbial antigens in the pathogenesis of reactive arthritis.

Baldassare et al have studied synovial biopsy specimens from patients with Reiter's syndrome and found deposition of IgM and C3, located predominantly in the vessel wall, in 11 out of 12 samples. ${ }^{14}$ Others have also shown the presence of immunoglobulin and complement components in the synovium of patients with Reiter's syndrome. ${ }^{15} 16$ Therefore, taking into account the higher concentrations of circulating yersinia-IgM ICs in patients with arthritis than in those without, ${ }^{3}$ it is possible that ICs in the synovial fluid are derived from the serum.

Another possible source of ICs in the joint is the presence of yersiniae or parts of them in the synovium, stimulating intra-articular formation of yersinia specific ICs, as is thought to occur in Lyme disease,$^{17}$ where spirochaetes were found in the synovium of two out of 17 patients $^{18}$ and in the synovial fluid of a patient with longstanding arthritis. ${ }^{19}$ We have also recently demonstrated yersinia antigens in the synovium of a patient with yersinia triggered reactive arthritis. ${ }^{20}$ Likewise, chlamydial antigens have been found in the synovium of patients with chlamydia triggered reactive arthritis. ${ }^{21} 22$

All these findings call into question definitions of postinfectious and reactive arthritis. Dumonde classifies arthritis as postinfectious when microbial antigen can be shown in the synovium or synovial fluid, and reactive in cases in which the microbial antigen is absent from the joint. ${ }^{23}$ An example of the former is arthritis after meningococcal meningitis, where meningococcal antigens have been demonstrated in the synovium or synovial fluid white cells. ${ }^{24}$ In this sense, it may prove that all reactive arthritides are postinfectious. Such a possibility is supported by all the indirect evidence indicating prolonged persistence of the yersinia antigens in patients with yersinia triggered reactive arthritis. ${ }^{1-3}$ 25-29

We thank Ms Tarja Laine for skilful technical assistance. This work was supported by the Finnish Medical Foundation, the Foundation of Turku University, the Sigrid Jusélius Foundation, and the US Public Health Service (grant 5 RO1 AM 33311, awarded by the National Institute of Arthritis, Diabetes, and Digestive and Kidney Diseases).

\section{References}

1 Toivanen A, Granfors K. Lahesmaa-Rantala R, Leino R, Ståhlberg T, Vuento R. Pathogenesis of yersinia-triggered reactive arthritis: immunological, microbiological and clinical aspects. Immunol Rev 1985; 86: 47-70.

2 Toivanen A. Toivanen P. eds. Reactive arthritis. Florida: CRC Press, (in press).

3 Lahesmaa-Rantala R, Granfors K, Kekomäki R, Toivanen A. Circulating yersinia specific immune complexes after acute yersiniosis: a follow up study of patients with and without reactive arthritis. Ann Rheum Dis 1987; 46: 121-6.

4 Theofilopoulos A N, Dixon F J. The biology and detection of immune complexes. Adv Immunol 1979; 28: 89-220.

5 McDougal J S, McDuffie F C. Immune complexes in man: Detection and clinical significance. Adv Clin Chem 1985; 24: $1-60$.

6 Sheldon P J H S. Mair N S. Fox E. Yersinia arthritis: a clinical, immunological, and family study of 2 cases. Ann Rheum Dis 1982; 41: 153-8

7 Granfors K. Measurement of immunoglobulin M (IgM), IgG, and IgA antibodies against Yersinia enterocolitica by enzymelinked immunosorbent assay: persistence of serum antibodies during disease. J Clin Microbiol 1979; 9: 336-41.

8 Lahesmaa-Rantala R, Granfors K, Toivanen A. Detection of circulating yersinia-immunoglobulin complexes by enzymeimmunoassay (EIA). J Immunol Methods 1986; 89: 191-9.

9 Kekomäki R, Penttinen K. Platelets and ${ }^{125}$ I-labelled staphylococcal protein $\mathrm{A}$ in the detection of immune complexes in serum. J Clin Lab Immunol 1979; 1: 305-9.

10 Viljanen M K, Ruuskanen O, Granberg C, Salmi T T. Serological diagnosis of pertussis: IgM, IgA and IgG antibodies against Bordetella pertussis measured by enzyme-linked immunosorbent assay (ELISA). Scand J Infect Dis 1982; 14: 117-22.

11 Lambert P H, Dixon F J, Zubler R H, et al. A WHO collaborative study for the evaluation of eighteen methods for detecting immune complexes in serum. J Clin Lab Immunol 1978; 1: $1-15$.

12 Kekomäki R. The reactivity of human platelets in the ${ }^{125} \mathrm{I}$ labelled staphylococcal protein A test. Acta Pathol Microbiol Immunol Scand /CI 1978; 86: 227-36.

13 Lahesmaa-Rantala R. Granfors K. Lehtonen O-P. Toivanen A. Characterization of circulating yersinia-specific immune complexes in patients with yersiniosis. Clin Immunol Immunopathol 1987: 42: 202-10.

14 Baldassare A R. Weiss T D. Tsai C C. Arthur R E. Moore T L. Zuckner J. Immunoprotein deposition in synovial tissue in Reiter's syndrome. Ann Rheum Dis 1981; 40: 281-5.

15 Brandt K D. Cathcart E S. Cohen A S. Studies of immune deposits in synovial membranes and corresponding synovial fluids. J Lab Clin Med 1968; 72: 631-47.

16 Yates D B. Maini R N. Scott J T. Sloper J C. Complement activation in Reiter's syndrome. Ann Rheum Dis 1975; 34: 468.

17 Hardin J A. Steere A C. Malawista S E. The pathogenesis of arthritis in Lyme disease: humoral immune responses and the role of intra-articular immune complexes. Yale J Biol Med 1984; 57: 589-93.

18 Johnston Y E, Duray P H, Steere A C, et al. Lyme arthritis. Spirochetes found in synovial microangiopathic lesions. $A m J$ Pathol 1985: 118: 26-34.

19 Snydman D R. Schenkein D P, Berardi V P, Lastavica C C, Pariser K M. Borrelia burgdorferi in joint fluid in chronic Lyme arthritis. Ann Intern Med 1986; 104: 798-800.

20 Toivanen A, Lahesmaa-Rantala R. Ståhlberg T, Merilahti-Palo $R$, Granfors $K$. Do bacterial antigens persist in reactive arthritis? Clin Exp Rheumatol (in press).

21 Schumacher H R Jr, Cherian P V, Sieck M. Clayburne C. Ultrastructural identification of chlamydial antigens in synovial membrane in acute Reiter's syndrome. Arthritis Rheum 1986; 29 (suppl): S31.

22 Keat A, Thomas B. Dixey J, Osborn M. Sonnex C. TaylorRobinson D. Chlamydia trachomatis and reactive arthritis: the missing link. Lancet 1987; i: 72-4. 
23 Dumonde D C. Introduction to part II. Principal evidence associating rheumatic discases with microbial infections. In Dumonde D C. ed. Infection and immunology in the rheumatic diseases. Oxford: Blackwell Scientific. 1976: 95-6.

24 Greenwood B M. Whittle H C. Bryceson A D M. Allergic complications of meningococcal disease II-immunological investigations. $\mathrm{Br}$ Med J 1973; ii: 737-40.

25 Granfors $K$, Viljanen $M$ K. Tiilikainen A. Toivanen A. Persistence of IgM, IgG and IgA class yersinia antibodies in yersinia arthritis. J Infect Dis 1980; 141: 4249.

26 Granfors K. Toivanen A. IgA-anti-yersinia antibodies in yersinia triggered reactive arthritis. Ann Rheum Dis 1986; 45: $561-5$.
27 Lahesmaa-Rantala R, Lehtonen O-P, Granfors K, Toivanen $\square$ A. Avidity of anti-yersinia antibodies in yersiniosis patients with and without yersinia-triggerer reactive arthritis. Arthritis Rheum (in press).

28 Ståhlberg T H, Granfors K, Pekkola-Heino K, Soppi E, Toivanen A. Immunoblotting analysis of human IgM, IgG and IgA response to chromosomally coded antigens of Yersinia enterocolitica O:3. Acta Pathol Microbiol Immunol Scand $/ C / \frac{\text { क }}{\vec{T}}$ (in press).

29 Ståhlberg T H, Granfors K. Toivanen A. Immunoblot analysis of human IgM, IgG and IgA responses to plasmid-encoded antigens of Yersinia enterocolitica serovar O3. J Med Microbiol $\overrightarrow{\vec{D}}$ (in press). 